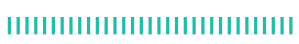

読み物シリーズ

IIIIIIIIIIIIIIIIIIIIIIIIIIIIII

各地の生産現場から

\title{
WEB版奈良県農作物病害虫防除指針について
}

\author{
井村岳男 ${ }^{1, *}$, 平山喜 彦 $^{2}$ \\ 1 奈良県病害虫防除所 \\ 2 奈良県農業水産振興課
}

（2017年11月 2 日受理）

\section{Nara plant protection guidance on WEB system}

\author{
Takeo Imura $^{1}$ and Yoshihiko Hirayama ${ }^{2}$ \\ ${ }^{1}$ Nara Pref. Plant Prot. Centr., Ikenouchi, Sakurai, Nara, Japan \\ ${ }^{2}$ Nara Pref. Agr. Fish. Dev. Div., Noborioji, Nara, Japan
}

Keywords: pesticide, plant protection guidance, web, Nara.

\section{はじめ に}

奈良県の平成27年度農産物産出額は338億円であり, 品 目別には水稲が最も多く 89 億円，次いでカキ 59 億円，イチ ゴ19億円，チャ 15 億円，キク 14 億円となっている．金額と しては決して多くないが，都市近郊にある立地のよさと自然 災害が少ない恵まれた環境条件を活かした農業を展開してい る.このような条件にあって，小規模ながら様々な品目が生 産されている．競争力の高い高品質な農産物生産のために は，的確な病害虫防除が重要である．病害虫防除の手段とし ては化学農薬の使用が今も多く, 県が作成する「農作物病害 虫防除指針（以下，防除指針）」に対するニーズは高い，

これまで，奈良県が作成する防除指針の在り方は，社会情 勢の変化を踏まえた様々な議論を経て変遷してきた。このよ うな中，奈良県では平成29年度に防除指針のWEB化を行っ たそそこで，ここに至るまでの本県の防除指針の変遷とその 概要を解説したい。

\footnotetext{
* 干 633-0046 奈良県桜井市池之内 130-1

E-mail: imura-takeo@office.pref.nara.lg.jp

(c) 日本農薬学会
}

\section{1. 都道府県病害虫防除基準について}

\section{1. 都道府県病害虫防除基準とは}

先述の防除指針は，一般には都道府県病害虫防除基準（以 下，防除基準）と称され，その名称は都道府県によって異な る. 防除基準とは，都道府県の病害虫防除に対する方針部分 と, 各都道府県で栽培されている主要な農作物で栽培上問題 となる病害虫の防除方法や推奨する農薬のリストを掲載した 部分から構成される資料であり，後者が防除指針と言われる ことが多い. 多くの場合は都道府県の農業技術指導者向け資 料として作成されており，防除を実施する際に使用する農薬 の選定などに活用される。

\section{2. 歴史的経緯}

都道府県が作成する防除基準は, 我が国の農業生産現場に おける病害虫防除において最も頻繁に参照される参考資料と 言える。しかし，いつ頃，どのような目的で都道府県がこう いった基準を作成するようになったのだろうか.

例えば，当所の書庫には，村瀬 吉という人物が執筆し， 昭和 5 年に発刊された「農作物病蟲害防除要覧」という古い 書籍か残っている. ${ }^{1)}$ 「農家, 農学生, 技術者に対する参考書 である」と書かれており, 作物ごとの主要病害虫の生態と防 除方法, 防除暦, さらに防除薬剤の使用方法が掲載され, 現 
在, 都道府県が作成している防除基準のプロトタイプとも言 える内容である.このような民間で作成された防除基準は古 くから存在したと考えられる.

一方，都道府県が作成する防除基準についてはどうであろ うか. 平成 17 年に改正された農水省の農作物有害動植物防 除実施要綱（16消安第9597号）の第2では，都道府県が防 除実施方針を定めて市町村長に示すこととなっているが，こ れは病害虫防除の考え方を表明するものである，具体的な防 除方法を記した防除基準の策定が求められているわけではな いにもかかわらず，全国のほぼすべての都道府県が防除基準 を作成しているのには何かの理由があったものと推察され る.

昭和 29 年に当時の農林省によって, 先の実施要綱に先立 つものとして, 病害虫防除実施要綱（29農改第2011号）が 制定された。ここでは, 市町村は都道府県が策定する防除実 施方針に即して，毎年，防除実施計画を定めることとされて いる.

さらに，昭和 44 年に発刊された「日本の植物防疫」とい う書籍にはこのような一文が見られる。 ${ }^{2)}$

「昭和 32 年ころから, 農林省は各市町村ごとに「病害虫防 除基準」を作成することを推奨した。…中略…この防除基準 に従って毎年の防除計画は容易に立案することができる」

また, 「佐賀の植物防疫史」には, 農薬不足による防除の 遅れを防止し，的確な防除を行うためには防除計画を策定し て, 計画的な農薬の製造, 備蓄, 配送が必要であり, この計 画策定の基礎になるのが防除基準であるということ，昭和 33年には稲作病害虫防除基準が全国に先駆けて，佐賀県で 作成された，という内容か記されている.

これらのことから, 市町村による防除実施計画策定の基礎 として防除基準の作成か推奨されたことを受けて, 防除実施 方針を定める都道府県が昭和 33 年頃から都道府県域の防除 基準を作成し始めたのではないかと推察される.

\section{2. 防除基準作成上の問題点}

\section{1. 農薬取締法改正に伴う状況の変化}

平成 14 年に発生したいわゆる「無登録農薬不正使用」の 問題に端を発し，同年に農薬取締法が改正された。この改正 で, 農薬使用者の責任が初めて法律上位置づけられ, 農薬登 録条件に合致しない方法で使用した者に対する罰則規定が 盛り込まれた。さらに平成 15 年には食品衛生法が改正され, 残留農薬基準のポジティブリスト制がスタートした。これに よって残留基準值が定められていない農薬については, 残留 濃度の規制基準として一律基準 $0.01 \mathrm{ppm}$ が適用されること となった。これ以降, 意図しない誤使用や周辺からのドリフ トによる, 残留基準值が定められていない農産物における残 留農薬検出事例であっても, 農薬取締法による罰則, あるい は食品衛生法に基づく回収義務が常に発生することとなっ
た. 生産現場に扔ける農薬使用は, 都道府県が作成する防除 基準に基づいて指導されることが多く, 万一防除基準の誤記 載に起因する不適正使用があれば，産地に対して取り返しの つかないダメージを与えるとともに，都道府県を相手取った 民事訴訟に発展しかねない事態となった。

それまで, 都道府県が作成する防除基準は, 利用者の便宜 を図り，可能な限り詳細な情報を掲載しょうとする想いを もって, 各都道府県が工夫を凝らして作成していた。 しか し, 人間が作成するものには間違いがつきものであり, 掲載 する情報を詳細にすればするほど䛊記載のリスクが高まる. 当時, 都道府県の担当者が, 今後も防除基準の策定を続ける べきかという点について議論を繰り返していたことが思い出 される。

\section{2. 防除基準作成における問題点と妥協点}

先の状況を踏まえて関係者間で様々な議論が重ねられた 結果, ほとんどの都道府県が防除基準作成を継続するという 判断を行った，その理由として，防除基準作成は様々な問題 点を孕んでいるものの, やはり利用者のニーズが高かったこ と, また生産現場の病害虫防除や農薬の適正使用指導に対し て一定の責任を持つ都道府県としても, 何らかの基準を示す 必要があるとの判断があったものと考えられる。これに伴っ て, 防除基準作成上の以下のような問題点が表面化してき た.

(1)作成時のチェックに膨大な労力がかかる

誤記載防止のための事前チェックがより厳密，かつ詳細に なされるようになり，2重3重のチェック作業にかかる時間 が膨大な負担となった。

(2)情報がすぐに古くなる

防除基準の作成は，通常は 1 2 年ごとに行われるのに対 し, 農薬登録内容は日及更新される。このため, 掲載された 情報がすぐに古くなり, 特に作成後に使用制限がかかった農 薬の扱いが難しい問題となった.

これらの問題点から, 奈良県では, 防除指針に盛り込む内 容を必要最小限に絞り込むとともに, チェック体制を強化し た。また，防除指針はあくまでも農薬選択の目安であって， 実際に指導，あるいは使用する際には登録内容を再度確認す る旨の記述か加えられた。

\section{WEB 版奈良県農作物病害虫防除指針}

\subsection{WEB 版導入の経緯}

近年, インターネット環境の急速な整備に伴って, WEB 上で防除基準を公開するシステムを構築するサービスを提供 する民間業者が現れたのは，自然な流れと考えられる。い つかの先進的な都道府県が導入したことを受けて, 奈良県で も防除指針のWEB化について検討した. その結果, 以下の ようなメリットが明らかとなった。 


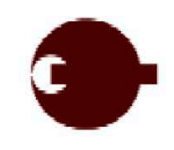

奈良県農薬情報システム

(農作物病害虫・雑草防除指導指針)
トップページ
農菜の検索
農菜データの一覧
配信ファイルの閲覧

奈良県からのお知らせ

\begin{tabular}{|c|c|c|}
\hline 2017/10/17NEW & 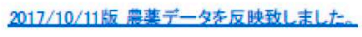 & \\
\hline $2017 / 10 / 05$ & 2017/09/30版 㶾蕉データを反映致しました。 & \\
\hline $2017 / 10 / 03$ & 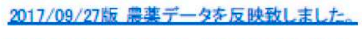 & \\
\hline $2017 / 09 / 21$ & 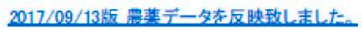 & \\
\hline $2017 / 09 / 06$ & 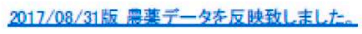 & \\
\hline
\end{tabular}

サービスご利用にあたって

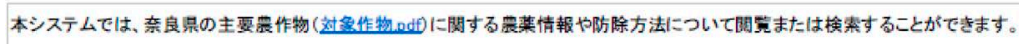

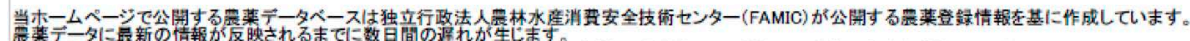

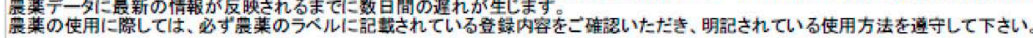

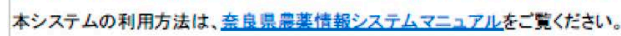

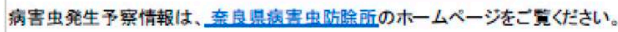

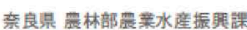

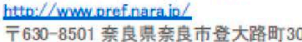

電話番号 (拉問い合わせ) :0742-27-7442

図1. トップページ.

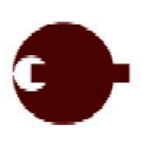

奈良県農薬情報システム

（農作物病害虫・雑草防除指導指針）

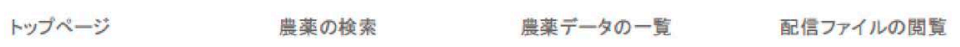

農薬の検索

\begin{tabular}{|c|c|c|c|c|}
\hline \multicolumn{5}{|l|}{ 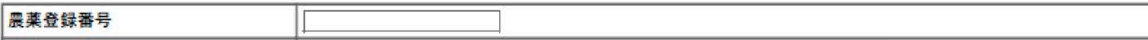 } \\
\hline \multicolumn{5}{|l|}{ 賑葉の名称 } \\
\hline 有勃成分の名称 & 口 & & & 橡索 \\
\hline 作物等の名称 & なす & & מעי & 娭索 \\
\hline 病害虫雓草名 & 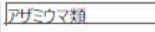 & & & 椣索 \\
\hline 用途 & 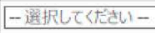 & $\checkmark$ & & \\
\hline 剂型 & - 選択してくくたさいい- & $\checkmark$ & & \\
\hline
\end{tabular}

検索

クリア

マッ゚ージの末尾人

114-1414のデータを表示(全 14件)

\begin{tabular}{|c|c|}
\hline 震宓確设 & アドマイヤー1精剂(No.18218) \\
\hline 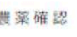 & アドマイヤーフロアブル(№.18562) \\
\hline 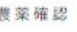 & モスピラン水流剖(No.19112) \\
\hline 辳壆磪诏 & アファーム乳剂(No.19842） \\
\hline 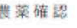 & オルトラン秢剂(No.19993) \\
\hline 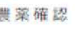 & スピノエース顆粒水和悋(No.20178) \\
\hline
\end{tabular}

図2. 検索結果. 
(1)作成作業の大幅な省力化

農薬登録条件のデータベースは業者が保有しており, 契 約した都道府県等は, 防除基準に掲載する作物と農薬を画 面上で選択するだけでよい，自ら推奨農薬一覧表を作成し， チェックする手間がほぼ全面的に省略されるので，大幅な省 力化が実現した.

(2)登録変更への対応が可能

従来の防除基準は, いったん作成すると次の作成まで内容
を変更するのが困難であり，すぐに情報が古くなるという問 題があった。しかし，WEB版ではシステムを提供する業者 が登録変更にかかる内容の更新をデータベース上で随時行う ため，防除基準の内容も自動的に更新される仕組みとなって いる.

(3)作成の低コスト化

奈良県の場合，CDでの防除指針作成とWEB版構築のた めの費用を比較すると, 人件費が大幅に圧縮されることか

\begin{tabular}{|c|c|}
\hline 贯菜登鋢番号 & 19842 \\
\hline 農菜の種類 & エマメクチン安息香酸塩乳㨈 \\
\hline 盲菜の名称 & アファーム乳風 \\
\hline 作用機權分類 & 虫：6[Iマメ午安息香酸堨] \\
\hline 申請者 & シンジェンタ ジャパン株式会社 \\
\hline 用送 & 殺虫斉 \\
\hline 剂型 & 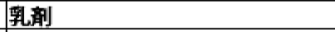 \\
\hline 登鐠日 & $1997 / 12 / 22$ \\
\hline 登錄期限 & $2018 / 12 / 21$ \\
\hline 備考 & \\
\hline
\end{tabular}

\begin{tabular}{|c|c|c|c|c|}
\hline 有効成分の名称 & 有効成分の種類 & 嗝度 & 毒性 & 魚毒性 \\
\hline エマメクチン安息香酸塩 & エマメクチン安息香酸塩 & $1.0 \%$ & 劇 (2\%普) & C \\
\hline
\end{tabular}

\begin{tabular}{|c|c|c|c|c|c|c|c|c|c|c|}
\hline 適用作物名 & 通用農菜名 & $\begin{array}{c}\text { 病害虫雑草 } \\
\text { 䓃 }\end{array}$ & $\begin{array}{c}\text { 希釈倍数使 } \\
\text { 用量 }\end{array}$ & 使用時期 & 使用方法 & $\begin{array}{l}\text { 本郕 } \\
\text { 使㽝 } \\
\text { 数 }\end{array}$ & 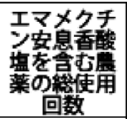 & 使用目的 & 敬布 & 備考 \\
\hline なす & & 䒔ザミウマ & 2000偣 & 收權前日ま & 散布 & $\begin{array}{l}\text { 2回以 } \\
\text { 内 }\end{array}$ & 2回以内 & & \begin{tabular}{|l|}
100 \\
$\sim 30$ \\
$0 \mathrm{~L} / 10$ \\
$a$
\end{tabular} & \\
\hline
\end{tabular}

図3. 詳細データ

\begin{tabular}{|c|c|c|c|c|c|c|c|c|c|c|c|}
\hline & 農薬の名称 & 有効成分の名称 & 作用機構分類 & 適用作物名 & 使用方 & 病害虫 & 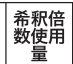 & 使用時 & $\begin{array}{l}\text { 本剤使 } \\
\text { 数 }\end{array}$ & 有効成分の総使用回数 & 備考 \\
\hline 1 & アグリメック & アハメクチン & 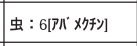 & なす & 散布 & $\begin{array}{l}\text { アザミ } \\
\text { ウマ類 }\end{array}$ & $\begin{array}{l}500 \sim 1 \\
000 \text { 倍 }\end{array}$ & 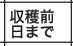 & 3回以内 & 3回以内 & \\
\hline 2 & アドマイヤー 1 粒剤 & イミダクロプリド & 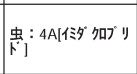 & なす & 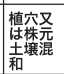 & アザミ゙ & $\begin{array}{l}1 \sim 2 g / \\
\text { 株 }\end{array}$ & 定植時 & 1回 & {$[* 1]$} & \\
\hline 3 & アドマイヤーフロアブル & イミダクロプリド & 虫：4A[隹名名ロプリ & なす & 散布 & $\begin{array}{l}\text { アザミ } \\
\text { ウマ類 }\end{array}$ & 4000倍 & \begin{tabular}{|l} 
收穫前 \\
\end{tabular} & 2回以内 & {$[* 1]$} & \\
\hline 4 & アドマイヤー顆粒水和剤 & イミダクロプリト & 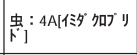 & なす & 散布 & $\begin{array}{l}\text { アザミ } \\
\text { ウマ類 }\end{array}$ & $\begin{array}{l}5000 \sim \\
10000 \\
\text { 倍 }\end{array}$ & 收縻㲖 & 2回以内 & {$\left[\begin{array}{ll}* 1] \\
\end{array}\right.$} & \\
\hline 5 & アファーム乳剤 & エマメクチン安息香酸塩 & 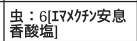 & なす & 散布 & $\begin{array}{l}\text { アザミミ } \\
\text { ウマ類 }\end{array}$ & 2000倍 & $\begin{array}{l}\text { 收穫前 } \\
\text { 前 }\end{array}$ & 2回以内 & 2回以内 & \\
\hline 6 & アルパリン顆粒水溶㜄 & ジノテフラン & 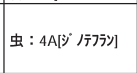 & なす & 散布 & アザミ & 2000倍 & 收磪揱 & 2回以内 & 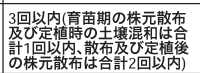 & \\
\hline 7 & オルトラン粒剂 & アセフェート & 虫: $1 \mathrm{~B}[$ P品 II-H] & なす & 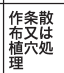 & \begin{tabular}{|l} 
アザミ゙ \\
ウマ類
\end{tabular} & $\begin{array}{l}3 \sim 6 \mathrm{~kg} / \\
10 \mathrm{a}(12 \\
2 \mathrm{~g} \text { (佅) }\end{array}$ & 定植時 & 1回 & 1回 & \\
\hline 8 & スタークル顆粒水溶剂 & ジノテフラン & 虫 : 4A[ジ ハテフラン & なす & 散布 & アザミ゙ & 2000倍 & 收權前 & 2回以内 & 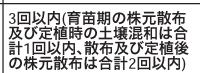 & \\
\hline 9 & スピノエース顆粒水和剤 & スピノサド & 虫：5[ズ 扸”] & なす & 散布 & \begin{tabular}{|l|} 
アザジ \\
ウマ類
\end{tabular} & \begin{tabular}{|l}
$2500 \sim$ \\
5000 倍
\end{tabular} & 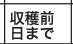 & 2回以内 & 2回以内 & \\
\hline 10 & ハチハチフロアブル & トルフェンピラド & 虫: 21A[トリフ工炕 ラ & なす & 散布 & $\begin{array}{l}\text { アザミ } \\
\text { ウマ類 }\end{array}$ & 1000倍 & 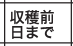 & 2回以内 & 2回以内 & \\
\hline 11 & ハチハチ乳剂 & トルフェンピラド & 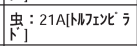 & なす & 散布 & $\begin{array}{l}\text { アザシ } \\
\text { ウマ類 }\end{array}$ & $\begin{array}{l}1000 \text { 和 } \\
\text { 2000倍 }\end{array}$ & 收穫前 & 2回以内 & 2回以内 & \\
\hline 12 & $\begin{array}{l}\text { ポリオキシンA L 水溶剤 } r ~ \\
\text { 科研」 }\end{array}$ & ポリオキシン複合体 & 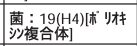 & なす & 散布 & $\begin{array}{l}\text { アザミ } \\
\text { ウマ類 }\end{array}$ & 5000倍 & 肾䅴前 & 3回以内 & 3回以内 & \\
\hline 13 & モスピラン水溶剤 & アセタミプリド & 虫 : 4A[アや多ブ 状 & なす & 散布 & アザミ゙ & $\mid \begin{array}{l}2000 \sim \\
4000 \text { 倍 }\end{array}$ & 收穕前 & 3回以内 & 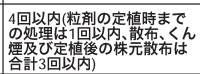 & \\
\hline 14 & モベントフロアブル & スピロテトラマト & 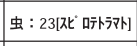 & なす & 散布 & \begin{tabular}{|l|l} 
アザミ゙ \\
ウマ類
\end{tabular} & 2000倍 & 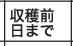 & 3回以内 & 3回以内(萑注は1回以内) & \\
\hline 15 & モベントフロアブル & スピロテトラマト & 虫: 23[즌 呼污外] & なす & 灌注 & $\begin{array}{l}\text { アザシ } \\
\text { ウマ類 }\end{array}$ & 500倍 & 㚆草期 & 1回 & 3回以内(濩注は1回以内) & \\
\hline
\end{tabular}

【*1】3回以内(育苗期の株元散布及び定植時の土溒混和は合計1回以内、散布及び常温煙霧は合計2回以内)

図4. 一覧表 
ら，相当な低コスト化をすすめることができた．

(4)検索の迅速性

手持ちのスマートフォンなどですぐに検索できるため, 従 来の冊子版や $\mathrm{CD}$ 版の防除基準に比べて, 農業技術指導者や 農業者が簡易に検索できるので，より利便性が高まった。

\section{2. 内容}

奈良県のWEB版防除指針の内容について簡単に紹介す る. ${ }^{4)}$ システムの名称は奈良県農薬情報システム（奈良県農 作物病害虫・雑草防除指導指針）としており，そのトップ ページを図 1 に示した。ページタイトルの下に, 検索ページ 等へのリンクボタンがあり，その下に登録変更データの更新 履歴が表示される．また，利用に当たっての注意点も記され ている.

図2 に検索ページとその検索例を示した。ここでは，「な す」の「アザミウマ類」で検索した場合の検索結果の一部 を掲載してある。さらに各農薬名の左にある「農薬確認」 のリンクをクリックすると，登録条件の詳細が表示される (図3)。さらに，検索した農薬の一覧を図4のような形でダ ウンロードすることもできる.

実際に使いこなすには多少の慣れが必要だが, 情報量は従 来の防除指針よりも多く，常に最新の登録内容に自動更新さ れるため, 利便性は高い, 今後はさらに, 農薬抵抗性の発達 を予防するための系統ローテーションを行うための基礎情報 として, 農薬の作用機作分類を示すRACコードを記入する など, 最近の農薬行政における諸課題への対応を少しずつ進 めていきたい。

\section{4.おわりに}

以上のように, WEB版の防除指針は従来の防除指針の問
題点の多くを解決し, 非常に有用なッールとなった。今回 の民間の力を借りた防除指針の WEB版への移行は様々なメ リットがあり, 行政業務の省力化に貢献できる取組であっ た．全国の都道府県において，防除基準をWEBシステムに 移行したのは本県を含めて未だ 10 県程度だが, 今後はこう いった取組が拡大していくものと思われる.

\section{引用文 献}

1）村瀬 吉：農作物病蟲外防除要覧, 明文堂, p. 200, 1930.

2）堀 正㑆：I. 5. 防除計画の立案, 日本の植物防疫, 社団法人日 本植物防疫協会, p. 12, 1968.

3）阿部恭洋：病害虫防除基準の作成経過, 佐賀の植物防疫史, 佐賀 県植物防疫協会, p. 117, 1992.

4) http://www.nouyaku-sys.com/noyaku/user/top/nara（2017年 10 月23日閲覧）

\section{略 歴}

井村岳男（いむら たけお）

生年月日：1968年3月 23 日

最終学歴: 京都府立大学大学院農学研究課修士課程農学専攻 修了

研究テーマまたは主な職歴：農業害虫管理

趣味：読書

平山喜彦（ひらやま よしひこ）

生年月日：1970年2月 5 日

最終学歴: 大阪府立大学大学院農学研究科博士前期課程修了

研究テーマまたは主な職歴：病害防除

趣味：スポーツ観戦 